\title{
TILL FABRIC AND DEFORMATIONAL STRUCTURES IN DRUMLINS NEAR WAUKESHA, WISCONSIN, U.S.A.
}

\author{
By SCOTT D. STANFORD* and DAVID M. MICKELSON
}

(Department of Geology and Geophysics, Weeks Hall, University of Wisconsin-Madison, Madison, Wisconsin 53706, U.S.A.)

\begin{abstract}
Deep gravel-pit exposures reveal the distribution and structure of till and underlying sand and gravel in drumlins near Waukesha, Wisconsin. The subglacial sediment is interpreted to have moved laterally into the drumlin sites because the till thickens from the margin to the core of the drumlins, the stone orientation in the till is perpendicular and oblique to ice flow on the drumlin margins, and recumbent isoclinal folds occur in sand on the drumlin margins with axes parallel to the drumlin axes. The resulting accumulations of sediment presented obstacles to ice flow and were streamlined into the minimum-drag drumlin shape by erosion on the margins and by remolding of material in the core of the drumlins. These drumlin nuclei may have formed at spots where there was low effective stress on the bed. The subglacial sediment became mobile as a result of high pore pressure that may have developed as ground water and subglacial melt water were trapped behind a frozen bed at the ice margin. Under certain conditions, however, lateral sediment flow might also have occurred when the sediment was frozen.
\end{abstract}

RÉsumé. Texture du matériel morainique et structures de déformation dans les drumlins près de Waukesha, Wisconsin, U.S.A. Des gravières entaillant profondément des drumlins près de Waukesha (Wisconsin) montrent la répartition et la structure des matériaux morainiques et des sables et graviers sous-jacents. Le sédiment sous glaciaire semble avoir été amené latéralement à l'emplacement du drumlin, car: l'épaisseur de moraine croît du bord vers le centre du drumlin, les pierres de la moraine sont perpendiculaires ou obliques par rapport au mouvement de la glace sur les bords du drumlin; le sable montre des plis isoclinaux couchés dont l'axe est parallèle à celui du drumlin sur les bords de ce dernier. Les accumulations de sédiments représentant un obstacle à l'écoulement de la glace ont été laminés par érosion sur les bords et remaniement du

\section{INTRODUCTION}

Drumlins are conspicuous and simple landforms. Their occurrence in groups and obvious relations to ice flow have intrigued investigators since the middle nineteenth century. With the work of Smalley (1966) and Smalley and Unwin (1968), researchers began to consider the strength of subglacial materials and the stresses to which these materials are subjected in an effort to explain how and why drumlins form (for a review of recent hypotheses, see Menzies (1979[b]) and Smalley (1981)). With this emphasis on process, drumlin studies acquire a broader relevance, because study of the stresses on and strength of subglacial material is important not only for an understanding of drumlin formation but also for an understanding of subglacial erosion, deposition, and deformation.

This paper is a description of the distribution and fabric of till and the structure of sand and gravel exposed in gravel pits in drumlins near Waukesha, Wisconsin. Inferences about the stresses on and strength of the

* Present address: New Jersey Geological Survey, CN029, Trenton, New Jersey 08625, U.S.A. matériel formant le noyau du drumlin pour atteindre la forme de drumlin qui offre le minimum de résistance. Ces germes de drumlin peuvent s'être formés là où la pression normale sur le lit était faible; le sédiment sous glaciaire devenent mobile lorsque la pression interstitielle est forte, ce qui peut se produire lorsque les eaux souterraines et les eaux de fusion de la glace sont emprisonnées derrière un lit gelé au front du glacier. Néanmoins, dans certaines conditions, un écoulement latéral du sédiment peut aussi avoir eu lieu lorsque le sédiment était gelé.

ZUSAMMENFASSUng. Geschiebegefüge und Verformungsstrukturen in Drumlins bei Waukesha, Wisconsin, U.S.A. Aufschlüsse in tiefen Kiesgruben lassen die Verteilung und Struktur von Schutt sowie von darunterliegendem Sand und Kies in Drumlins bei Waukesha, Wisconsin, erkennen. Es wird angenommen, dass das subglaziale Sediment sich seitlich in die Drumlinlagen geschoben hat, da der Schutt vom Rande zum Kern der Drumlins an Dicke zunimmt, da die Orientierung der Steine im Schutt senkrecht und schräg zum Eisfluss an den Drumlinrändern verlăuft und da liegende, isoklinale Falten im Sand an den Drumlinrändern mit Achsen parallel zu den Drumlinachsen auftreten. Die sich hieraus ergebenden Anhäufungen von Sediment setzten dem Eisfluss Hindernisse entgegen und erhielten durch Erosion an den Rändern und durch Nachschub von Material zum Kern der Drumlins die stromlinienförmige Drumlinform geringsten Widerstandes. Diese Drumlinkerne dürften sich an Stellen gebildet haben, wo niedrige Normalspannungen am Bett herrschten. Das subglaziale Sediment wurde infolge hohen Porendruckes beweglich, der sich entwickelte, als Grundwasser und subglaziales Schmelzwasser hinter einem gefrorenen Bett am Eisrand eingeschlossen war. Doch mag unter gewissen Bedingungen auch seitlicher Sedimentfluss aufgetreten sein, wenn das Sediment gefroren war.

subglacial material during drumlin formation are then drawn from these observations. This study is an expansion and continuation of the work of Whittecar (unpublished) and Whittecar and Mickelson (1977, 1979), who first described and interpreted the till stratigraphy and deformational structures in these drumlins. Previous workers in this area include Alden (1905, 1918), who first described the morphology and regional distribution of the drumlins, and Evenson (1971), who measured fabric in several drumlins as part of a general study on the origin of till fabric.

Drumlins in south-eastern Wisconsin occur in two fields: a small field near Waukesha formed by ice of the Lake Michigan lobe, and a large, $80 \mathrm{~km}$ wide arcuate belt of drumlins behind the southern terminus of the Green Bay lobe (Fig. 1). In this study, nine drumlins in the Waukesha field and two in the Green Bay field were examined (Fig. 1). Based on the correlation of the drumlin-forming New Berlin till (Mickelson and others, 1984) with the Haeger till in Illinois, and with till of the Johnstown and Darien moraines in Wisconsin, both the Waukesha and Green Bay drumlins are thought to have formed during advance of ice to the Darien and Johnstown moraines approximately 14500 B.P. (Whittecar and Mickelson, 1979). The Waukesha drumlins are clustered on uplands (Whittecar, unpublished) 

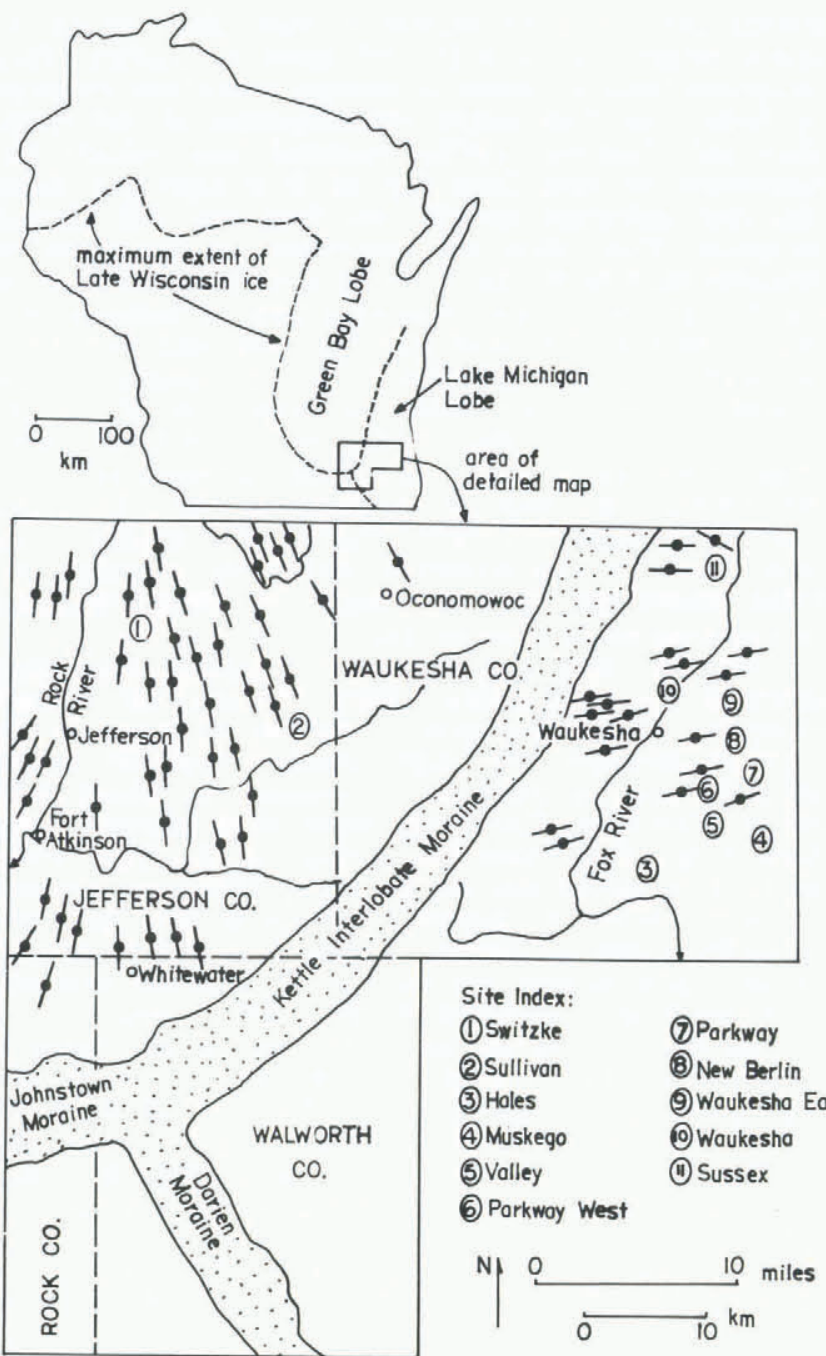

Fig. 1. Map of Wisconsin and detailed location map with drumlin trends, prominent moraines, and modern drainage (after Alden, 1918).

and are commonly overlapping or composite in form. The clusters are probably on interfluves between stream valleys cut through a pre-existing outwash plain. Unlike small gravel-cored drumlins described by Krüger and Thomsen (1984), much of the drumlin form here is eroded into this pre-existing outwash by ice. The Green Bay lobe drumlins are generally longer and narrower than the Waukesha drumlins (Mills, 1980, unpublished), and are discrete hills with a less marked tendency to cluster on uplands.

\section{DISPOSITION OF TILL IN THE DRUMLINS}

Both the Green Bay and the Waukesha drumlins are at least partially cored and carpeted with a very pale brown (10YR 7/4) sandy loam or loam till. Grain-size analyses on more than 60 samples of the till yielded an average of $64 \%$ sand $(2.0-0.0625 \mathrm{~mm}), 27 \%$ silt $(0.0625-0.002 \mathrm{~mm})$, and $9 \%$ clay $(<0.002 \mathrm{~mm})$ in the $<2 \mathrm{~mm}$ fraction. In places, till near the surface of the drumlin is enriched in sand and contains stratified sandy and pebbly lenses that we interpret as patches of supraglacial debris let down atop the drumlins during final melting (Johnson and others, 1982), but the bulk of the till in the drumlins has a uniform, well-compacted matrix and was probably deposited subglacially. In all but one of the drumlins, where the base of the till is exposed, the till is thickest in the center of the drumlin. The lower contact of the till dips downward as the drumlin surface rises, proceeding from the margin to the core of the drumlin, defining a pod-shaped body of till that is thickest beneath the drumlin crest. Figure 2 summarizes thickness measurements in five drumlins and demonstrates thickening of the till toward the center of the drumlins. This pattern indicates that preferential accumulation of till occurred at the drumlin sites. In a few places, the till can be separated into a lower deformed unit of basal till and an upper, undeformed basal till unit that conforms to the drumlin shape, suggesting that there were two episodes of subglacial deposition during the drumlin-forming glaciation - possibly one during ice advance and the other during retreat of the ice - separated by a period of erosion, deformation, and drumlin formation (Whittecar and Mickelson, 1977).

\section{TILL FABRIC}

In order to investigate the structure of the drumlin-forming till, fabric was measured at 84 sites in ten drumlins. For each fabric measurement, azimuth and plunge of 25,30 , or 50 pebbles were determined using a Brunton compass. Only pebbles with long axis to intermediate axis ratios of $3: 2$ or greater were measured. The vast majority of pebbles measured were dolomite, usually prolate ellipsoids.

Fifty pebbles are commonly accepted as the minimum number for a reliable fabric, although 25 pebbles may accurately depict the orientation maxima (Young, 1969; Grieco, unpublished). In the course of measuring fabric for this study, comparison of the orientations obtained from the first 25 pebbles of a 50 pebble sample with the 50 pebble orientation showed that, for fabrics with clearly defined maxima, plots of the first 25 pebbles faithfully replicated the 50 pebble plots to within $10^{\circ}$. Based on this observation, 25 (or 30 ) pebble measurements were judged to be adequate if they showed a clear maximum; if no clear maximum appeared, 50 pebbles were measured. Using this technique, 25 pebbles were measured at 36 sites, 30 pebbles were measured at four sites, and 50 pebbles were measured at 44 sites. The fabric data were then plotted by computer on equal-area projections of lower hemispheres using the

$$
\begin{aligned}
& \text { - Woukesho } \\
& \Delta \text { Porkwoy } \\
& \text { - Sussex } \\
& + \text { New Berlin } \\
& \text { - Holes }
\end{aligned}
$$

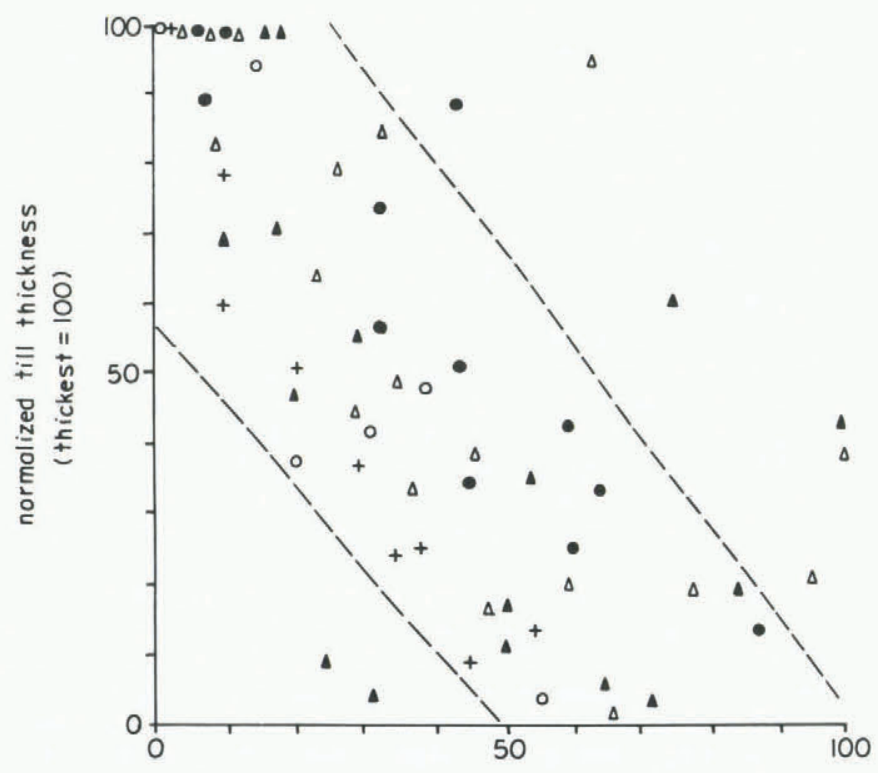

normalized distance from center of drumlin (center $=0$, margin $=100$ )

Fig. 2. Summary plot of till thickmess from margin to core of five drumlins indicating thickening of till towards drumlin cores. 
method of Kamb (1959) (computer program by C. Corbato, Ohio State University).

The origin of till fabric has been the subject of a number of papers. In theory, elongated particles immersed in a flowing medium (whether it be water, ice, or viscous sediment) will orient to attain a position of minimum torque. Rusnak (1957) presented the following equation for the torque $(T)$ on a particle in terms of the fluid density $(\rho)$, fluid velocity $(\mu)$, length of the long $(a)$ and intermediate $(b)$ axes of the particle, and the angle $(\boldsymbol{\beta})$ between the $a$-axis of the particle and the mean velocity vector

$$
T=-\pi \rho\left(a^{2}-b^{2}\right) \mu^{2} \sin \beta \cos \beta .
$$

The torque goes to zero, indicating a stable position, when $\beta$ equals $\pi / 2$ (that is, when the long axis is transverse to flow) and when $\beta$ equals $\pi$ (that is, when the long axis is parallel to flow [longitudinal orientation]).

For a lone particle lying parallel to flow, slight velocity fluctuations in the fluid will tend to rotate the particle into a transverse alignment; thus, the transverse position is more stable. But, if a number of particles impinge on each other in the fluid, the transverse orientation gives rise to frequent collisions, and the longitudinal orientation is more stable. A longitudinal orientation would also be expected in extending flow, where fluid in front of the particle is moving faster than fluid behind the particle, thus tending to rotate the front of the particle parallel to the flow direction. Therefore, in a pebble-rich material such as till or debris-laden ice, a longitudinal orientation would be expected to be the stable condition and fabric maxima should indicate the direction of movement of the ice or of viscous till.

However, transverse orientations in debris-rich material have been described in areas of compressive flow, where fluid above and behind the particle is moving faster than fluid below and in front. For example, transverse fabric is observed on the margins of debris flows and in sheared-up debris bands in ice (Boulton, [ $\left.{ }^{c} 1971\right]$ ). Possibly, this transverse fabric is produced by the velocity gradient set up across the up-flow and down-flow ends of a particle in longitudinal orientation when it enters a compressive-flow regime. Fluid moving against the up-flow end of the particle will have a slightly higher velocity than fluid moving at the down-flow end. Any slight fluctuation in the flow direction will thus set up a torque tending to rotate the up-flow end until a transverse orientation is attained, and there is no appreciable velocity gradient across the particle. In general, then, a longitudinal fabric forms in extending flow and in debris-rich flow, and a transverse fabric forms in compressive flow and in debris-poor flow.

Till fabric has commonly been interpreted as being produced englacially and preserved upon melting out or mass lodgement (Glen and others, 1957; Harrison, 1957; Boulton, [ $\left.\left.{ }^{c} 1971\right]\right)$, or produced during particle-by-particle lodgement at the sole (Holmes, 1941). MacClintock and Dreimanis (1964) demonstrated re-orientation of fabric in wet till during a later advance and established that post-depositional flow of till can create a fabric. Based, in part, on their work, Evenson (1971) interpreted fabric in the Green Bay lobe drumlin field as the product of post-depositional movement of viscous till. Englacial and lodgement-till fabric, then, reflect local ice-flow direction, whereas post-depositional fabrics (produced either in supraglacial or subglacial environments) record the flow direction of viscous till, which may not coincide with ice flow.

The till fabric of drumlins and flutes has been studied in a number of areas. Donner and West (1955), Wright (1957), Evenson (1971), and Walker (1973) all reported fabric that is generally parallel to the drumlin axis. Young (1969) and Hill (1971) found that drumlin fabric has steeper plunges and tends to be weaker than fabric in till plains. Hill (1971) and Krüger and Thomsen (1984) also noted that some fabric deviates considerably (more than $30^{\circ}$ ) from the drumlin axis; this deviation is attributed to deflection of ice around the flanks of the drumlins. Gravenor and Meneley (1958), based on microfabric measured in flutes and drumlins in Alberta, also reported deviation of fabric maxima away from the drumlin or flute axis, especially at depths greater than $3 \mathrm{~m}[10 \mathrm{ft}]$ below the surface. They interpreted these deviations as remnant orientations produced by former ice flow before superimposition of the flutes. Shaw and Freschauf (1973) measured both micro- and macrofabric in large flutes (up to $20 \mathrm{~m}$ high) and found that they converged towards the flute axis and plunged up-glacier. This fabric was interpreted as the record of helicoidal flow in the ice, with till accumulated in flutes at the convergence of upward-rotating parts of adjacent flow cells. Boulton (1976) found that fabric in small-scale flutes in Svalbard points into the flute and plunges steeply beneath the flute crest, indicating squeeze-up of till into subglacial cavities formed in the lee of obstacles. Savage (unpublished) and Grieco (unpublished) measured fabric on the margins and ends of drumlins in New York and observed accordance of fabric maxima with expected flow lines of ice moving plastically around the drumlin. This fabric pattern was cited as evidence for drumlin accretion by plastering-on of layers of till.

For the most part, these investigations have been restricted to near-surface fabric because of shallow exposures. Little information is available on fabric in the cores of drumlins. The deep exposures available in the Waukesha area afforded an opportunity to obtain such fabric information. Fabric was measured at depths ranging from 2 to $39 \mathrm{~m}$ below the surface. At 11 sites, where gullies were eroded into the pit walls, fabric was measured at several depths to determine vertical as well as lateral variability within the drumlin. Figures 3,4 , and 5 are maps of three pits showing the location of structural data and lower-hemisphere projections of fabric measurements.

As can be seen on the maps, most of the fabric is parallel to the drumlin axes but fabric that is perpendicular and oblique to ice flow is not uncommon (Figs 4 and 5). The perpendicular fabric tends to occur between the margin and core of the drumlins at depths greater than $6 \mathrm{~m}$ and, where overlying fabric can be measured (e.g. Fig. 5), it is parallel to ice flow. Three of the perpendicular fabric measurements are close to the surface and may be in slumped material (or in supraglacial till), but the other 14
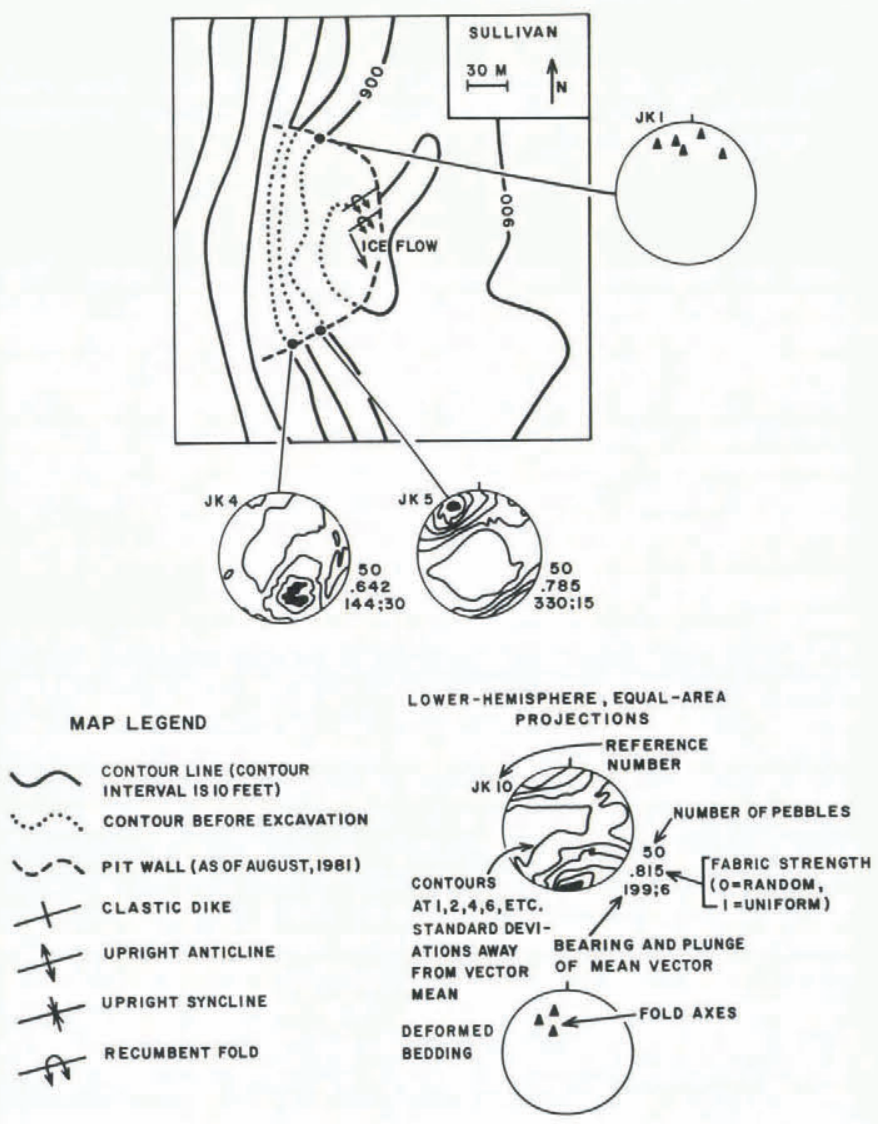

Fig. 3. Sullivan pit map and legend for maps in Figures 4 and 5. Note relation of fold axes to ice flow. 


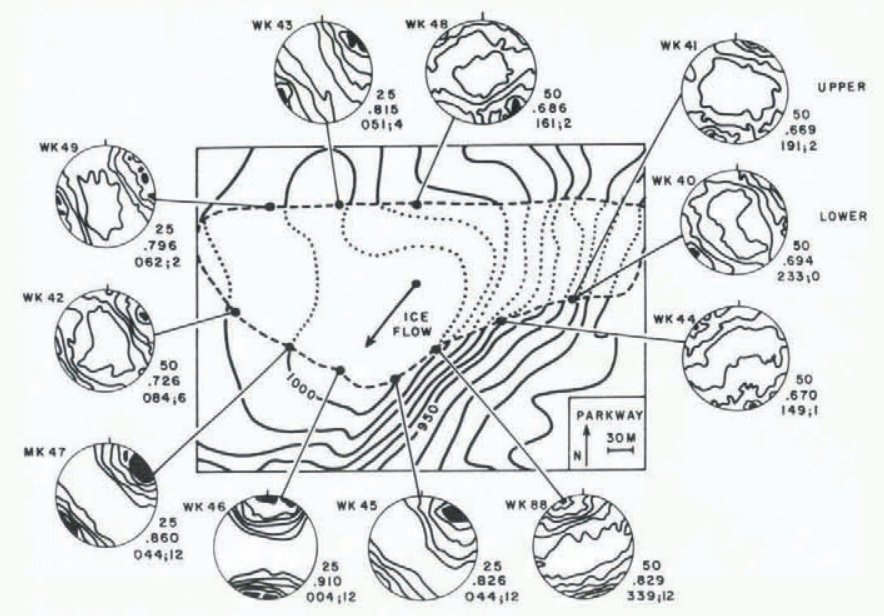

Fig. 4. Parkway pit map. Note perpendicular fabric (WK48, WK44, WK88).

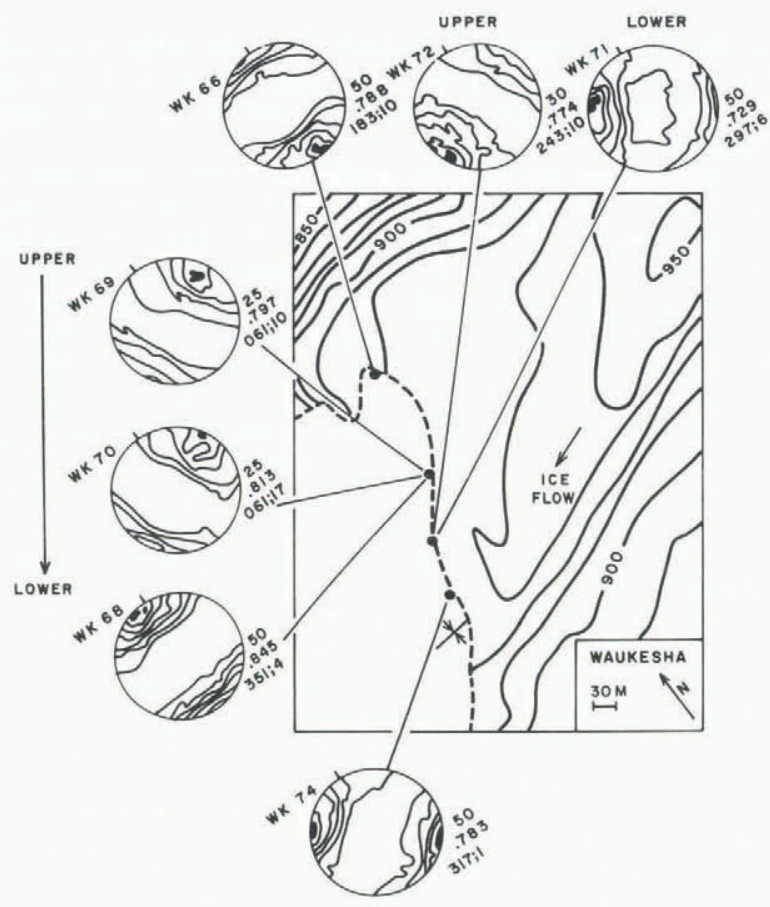

Fig. 5. Waukesha pit map. Note perpendicular fabric (WK66, WK71, WK68, WK74).

perpendicular measurements are in uniform basal till that is clearly traceable to, and is not visibly or analytically different from, till having the parallel fabric.

Given its position in the drumlins, it is unlikely that the perpendicular fabric is a transverse fabric produced by compressive flow in the ice itself or by compressive conditions transmitted from the ice into the underlying till during drumlin formation. In accordance with Bernoulli's theorem, fluids will have greater pressure and slower velocity (a compressive regime) on the up-flow end of an obstacle, but on the sides and down-flow end of the obstacle the pressure is less and velocity is greater, thereby defining an extending flow regime (see also Savage, unpublished). Ice depositing or molding till into a drumlin then would not be under compressive flow at the marginal position in which the perpendicular fabric is commonly found.

One interpretation of fabric perpendicular to ice flow is that the perpendicular fabric is actually a longitudinal fabric formed by lateral flow of remobilized till toward the drumlin site rather than fabric created by shear or deposition from flowing ice. This remobilization fabric is similar in origin to the fabric in flutes described by Boulton (1976). The fabric pattern described by Shaw and
Freschauf (1973) and the anomalous fabric orientations perpendicular and oblique to drumlin axes observed by other authors (see above) may have a similar origin. Such fabric, as the product of flow within previously deposited till, may be wholly independent of the ice-flow direction.

Fabric parallel to ice flow is more common and is found in the cores and on the margins near the surface of the drumlins. Parallelism with ice flow suggests that such fabric is primarily a longitudinal fabric produced during original deposition rather than a remobilization fabric. This deposition, however, was probably not synchronous with drumlin formation, because, if large-scale deposition of till occurs primarily in a zone near the margin, as suggested by many authors (for example, Sugden and John, 1976; West, 1977; Whittecar and Mickelson, 1979), and if drumlins are formed up-ice from this zone of deposition (Whittecar and Mickelson, 1979), it is unlikely that primary deposition from ice at the time of drumlin formation is the agent responsible for the bulk of the till in the drumlin or for the fabric of that till. Instead, the parallel fabric found in most of the till in the drumlin may have been produced either during pre-drumlin subglacial deposition or it may be post-depositional fabric imprinted during shearing of till by ice moving over and around the drumlin. This latter possibility is particularly applicable to fabric parallel to ice flow that is found just above till with a perpendicular fabric.

\section{STRUCTURE OF THE SAND AND GRAVEL}

Thick sand and gravel occurs beneath the till in the drumlins. It is predominantly either horizontally bedded or tilted and truncated by the till. However, intense deformation is not unusual, especially in sand. Thi deformation is of three types: (1) recumbent isoclinal folds, (2) upright isoclinal to open folds, and (3) clastic dikes. Faults, although described by Whittecar (unpublished), were not observed in exposures between 1981 and 1983.

The recumbent isoclinal folds occur between the edge and core of the drumlins, usually under relatively thin till (1.5-6 m thick). Orientation of the axes of these folds is consistent at a given location and axes tend to be either nearly perpendicular to the drumlin axis or nearly parallel to the axis (Fig. 3). Where the folds occur in sand (Fig. 6), amplitudes are on the order of $0.3-1 \mathrm{~m}$; wavelengths are usually less than $0.6 \mathrm{~m}$. In gravel, amplitudes are more than $3 \mathrm{~m}$ and wavelengths are approximately $1.5-3 \mathrm{~m}$. This difference in size is due both to the thicker bedding in the gravel and to the greater angle of internal friction of the gravel (both in the dry and frozen state). The greater angle of internal friction of the gravel imparts a greater shear strength than that of sand and hinders internal deformation, thereby preventing small-amplitude folds.

The recumbent folds with axes perpendicular to ice flow are probably drag folds produced by shear from over-riding ice. Recumbent folds with axes parallel to the drumlin axis are probably not the result of drag from

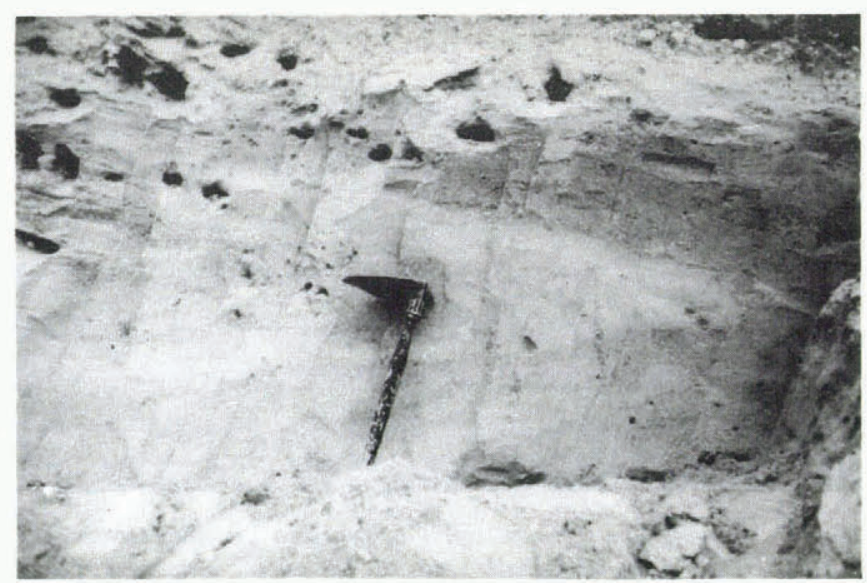

Fig. 6. Photograph of a recumbent isoclinal fold in sand. The fold axis is parallel to the drumlin axis. 
over-riding ice. Instead, these folds may be similar to recumbent folds that have been observed and experimentally produced in liquefied sand.

Williams (1960) observed that loosely packed fine sand and silt will collapse if sheared. If such sediment is saturated, confined, and then sheared, it will liquefy; that is, its shear strength will drop as the loose packing disintegrates and the pore fluid assumes the load. Liquefaction, in turn, may allow flow if an external force is applied (as, for example, by unequal vertical loading). Flow will be laminar and recumbent folds will develop as manifestations of flowing bands moving at different velocities. Fold axes will be perpendicular to the flow direction. Similar behavior has been described by McKee and others (1962) for a sand layer confined by silt strata. They found that high pore pressure in the sand led to recumbent folds where a horizontal pore-pressure gradient occurred across the sand layer.

Applying these observations to the recumbent folds with axes parallel to the drumlin axes suggests that they formed by flow of liquefied sediment toward the drumlin site, either in response to a greater weight of ice in the inter-drumlin areas or to flow of water through the sediment toward the drumlin site. The parallelism of the fold axes with ice flow rules out drag from over-riding ice, and the regularity of the folds and lack of thinning or thickening of the beds argues against a down-slope slump origin. Sites where fold axes adopt oblique or ambiguous orientations with respect to the drumlin axis may have undergone two folding episodes: an original set produced by flow toward the drumlin and a later set produced by ice drag, resulting in a deformational pattern similar to that described by Boulton (1976) in modern flutes.

Upright folds are less common, though more spectacular, than the recumbent folds. They occur singly and are of much larger amplitude (as much as $12 \mathrm{~m}$ ) than the recumbent folds, suggesting the presence of a larger-scale stress field. These folds are composed of sand, gravel, and till layers (Fig. 7), and are found both on the margin and in the core of the drumlins. Axes of these folds are both parallel and perpendicular to ice flow.

The origin of these upright folds is more problematic than that of the recumbent folds because no clear analog exists in non-glacial sediment. Those folds having axes perpendicular to ice flow may be ice-push folds that did not become overturned and were later truncated by erosion. The marginal folds with axes parallel to ice flow are probably not related to the ice flow, and the presence of silt, gravel, and thin till layers, as well as their upright, large-amplitude geometry and isolated occurrence, rules out liquefied sediment flow because horizontal flow of liquefied sediment would not produce upright folds involving several sediment layers folded concordantly. One possibility is that they are compressive folds produced by the weight of sediment in the drumlin (and of the ice overlying the drumlin) acting laterally against the drumlin margin. Under

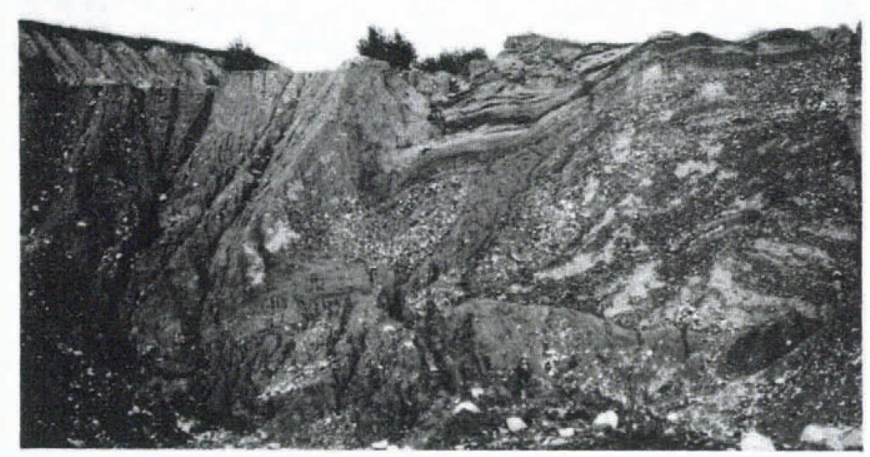

Fig. 7. Photograph of an upright syncline in Waukesha pit. The fold axis is parallel to the drumlin axis. Ice flow was out of the photograph. Amplitude of visible folds about $10 \mathrm{~m}$.

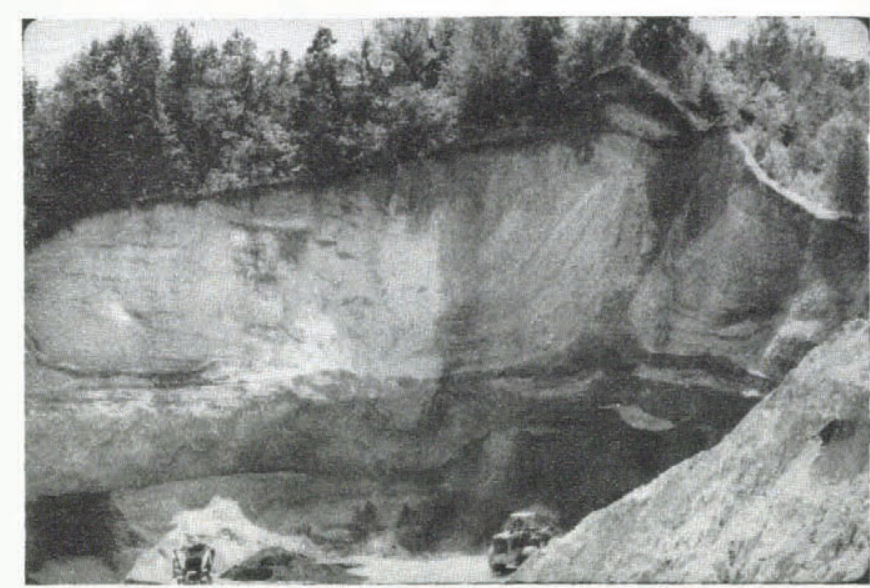

Fig. 8. Photograph of a clastic dike in Valley pit. Trend of the dike is parallel to the drumlin axis. Ice flow was directly into the photograph.

these conditions, upright marginal folds of large amplitude might be formed locally if high pore pressure lowers the yield strength of the sediment so as to permit ductile deformation.

Clastic dikes are vertical bodies of layered sand and, in some cases, gravel and till, which intrude upward into and, at places, through the upper till (Fig. 8). They are usually found in the drumlin cores and commonly trend parallel to the drumlin axis, although several dikes described by Whittecar (unpublished) are perpendicular to the drumlin axis. Dike widths range from $1 \mathrm{~m}$ to $9 \mathrm{~m}$; vertical dimensions are more obscure because the bottoms of the dikes are rarely exposed. Minimum vertical dimensions range from $1.5 \mathrm{~m}$ to $6 \mathrm{~m}$. At two sites where longitudinal dimensions could be observed, the dikes were linear and tabular in shape, although Whittecar (unpublished) described several dikes which were domes or doubly plunging antiforms.

Till fabric was measured in and near the dikes at two locations. Fabric in the intruded till adjacent to the margins of the dikes does not show steepened plunge but does tend to be re-oriented toward the dike. Fabric in till in the dikes or immediately next to the dikes does show steepened plunge. These findings suggest that the till enclosing the clastic dike did not deform in concert with the material in the dike but rather acted as a rigid layer into and through which the underlying sediment intruded. Where dikes can be seen to intrude sand and gravel, bedding next to the dike is deformed but the dike penetrates the bedding of the gravel (Fig. 8).

A striking feature of the clastic dikes is the preservation of primary stratification. Stratification, defined by interbedded layers of varying grain-size, is always continuous, parallel to the dike walls, and only rarely interrupted by isolated, small-scale intrafolial isoclinal folds (with axes parallel to the dike). At several sites this stratification is traceable laterally to horizontal strata, indicating that it is primary stratification and not flow-banding.

Stratification is not commonly observed in dikes in sedimentary rocks (Potter and Pettijohn, 1963) and, where it has been described (Waterson, 1950; Peterson, 1968), it is interpreted as an intrusion phenomenon rather than as primary depositional layering. This absence of primary bedding in dikes in sedimentary rocks is perhaps the result of turbulent flow during injection, or of the massive or thickly bedded character of the source beds. Presumably, however, there is a continuum from low-viscosity, rapid-injection density-inversion structures such as clastic dikes, in which turbulent flow occurs and bedding is not preserved, to high-viscosity, diapiric density-inversion structures such as salt domes or load structures in which laminar flow occurs and bedding is preserved. The fact that bedding is preserved in at least some drumlin dikes, then, is indicative of a laminar, diapiric-type rise of low-density, liquefied sediment into a denser, rigid till or sand and 
gravel cap. The presence of thin layers of till and gravel (which do not reaily undergo liquefaction) in the dikes perhaps indicates that either movement of the enclosing liquefied sand was capable of deforming the interstratified till and gravel or that gravel and till strata were penetrated and upwarped, and included by the upwelling sand (Whittecar, unpublished).

\section{MECHANICAL BEHAVIOR OF SUBGLACIAL MATERIAL}

The till fabric, folds, and clastic dikes described above are indicative of ductile deformation of the till, sand, and gravel, but they provide no direct indication of whether the sediment was wet or frozen, or of the magnitude of the normal and effective stresses at the base of the ice. The following discussion is an attempt to address these issues.

The ability of sediment to deform is dependent on the grain-size and the water (or ice) content of the sediment; the direction, magnitude, and distribution of the subglacial stresses; the strain-rate; and the duration of stress application. In general, fine grain-size, abundant water, large confining stresses, slow strain-rates, and long durations of stress application encourage ductile behavior (deformation by plastico-viscous yield); coarse, dry materials subjected to quick loading behave elastically (deformation by brittle fracture) (Scott, 1979; Kaplar, 1971). Any postulated value for these quantities in the subglacial environment well behind the margin where drumlins form is of necessity speculative. However, some plausible statements can be proferred based upon assumed basal conditions and ice thickness.

Wet conditions would be expected at the base of a temperate glacier or at the base of a sufficiently thick polar glacier owing to geothermal melting of ice at the pressure-melting point. If the subglacial water is slowly drained or not drained, sediment will be saturated and the pore pressure will increase. The effect of pore pressure on the shear strength of the sediment is expressed by the Mohr-Coulomb equation

$$
S=C+\left(\sigma_{\mathrm{n}}-u\right) \tan \phi .
$$

As pore pressure $(u)$ increases, the effective stress $\left(\sigma_{\mathrm{n}}-u\right)$ decreases and the shear strength $(S)$ is diminished $(C$ is the cohesion and $\Phi$ is the angle of internal friction). Therefore, in saturated conditions where high pore pressure exists, the shear strength of the sediment is lowered and deformation results if the high pore pressure is not balanced by greater normal stress. The style of deformation might be analogous to the behavior of debris-flow material that is texturally similar to till. As analyzed by Johnson (1970), debris flows behave as a plastico-viscous substance; that is, they flow viscously once a yield strength is surpassed. Below this yield strength, little or no permanent deformation occurs. If this rheologic analogy is valid, perpendicular fabric in the till and folding in the sand and gravel could be the manifestations of viscous flow of sediment into the drumlin site when it is subjected to a shear stress greater than its yield strength.

Rough estimates of basal normal stress and shear stress can be calculated knowing the ice-surface profile and the unit weight of ice, but subglacial pore pressure and the yield strength and viscosity of wet sediment under confined conditions are unknown. However, the existence of squeeze-up till ridges near the margins of modern glaciers under thin ice (Boulton, 1976) and the prevalence of softsediment deformation in fluvial and marine environments demonstrate that, where pore pressure is high, yield strengths are often sufficiently small to permit sediment flow. High pore pressure in the subglacial environment could arise from blockage of ground-water discharge areas by ice and from trapping of basal melt water behind a frozen-bed margin or in material of low hydraulic conductivity (Boulton, [ $\left.{ }^{\mathrm{c}} 1975\right]$ ).

Ductile failure can also occur under frozen conditions. Uniaxial and triaxial compression tests and direct shear tests have been performed on frozen soils by the U.S. Army Corps of Engineers (Scott, 1969; Kaplar, 1971; Sayles, 1974; Sayles and Haines, 1974; Haynes and Karalius, 1977) and by Russian engineers (Tsytovich, [ $\left.{ }^{c} 1975\right]$ ) under a variety of strain-rates, temperatures, ice contents, and grain-sizes. In general, it is observed that at high strain-rates brittle deformation occurs; at low strain-rates ductile deformation occurs. Plastico-viscous yield strength (the "creep strength" or "ultimate strength") is an order of magnitude lower than brittle strength (Scott, 1969; Sayles and Haines, 1974) and was found to increase as confining pressure increased (Alkire and Andersland, 1973; Sayles, 1974), temperature decreased, and strain-rate increased (Sayles and Haines, 1974). Maximum compressive strength (ranging from 6300 $\mathrm{kN} \mathrm{m}{ }^{-2}$ for coarse sand to $9100 \mathrm{kN} \mathrm{m}^{-2}$ for fine sand) was observed for ratios of volume of ice to volume of soil between 0.2 and 0.4 for coarse sand and between 0.4 and 0.7 for fine sand (Kaplar, 1971). At smaller and larger ice contents, compressive strength dropped to less than 1400 $\mathrm{kN} \mathrm{\textrm {m } ^ { - 2 }}$ for both fine and coarse sand.

Ductile failure of frozen soil, then, is favored by slow strain-rates, temperatures close to freezing, and ice-to-soil ratios less than approximately 0.3 or greater than approximately 0.6. Most of the yield-strength values reported by the U.S. Corps of Engineers and by Tsytovich [ $\left.{ }^{c} 1975\right]$ ) are derived from uniaxial (unconfined) compressive testing and so are not directly applicable to the confined conditions beneath the ice. Sayles (1974), however, conducted triaxial creep tests on frozen sand at $-3.8^{\circ} \mathrm{C}$ (ice-to-soil ratio approximately 0.6 ) and at various strain-rates. He found that the creep-strength failure envelope leveled off at confining pressures greater than $2700 \mathrm{kN} \mathrm{m}^{-2}$ and that lowering the strain-rate caused yield at lesser shear stresses. Kaplar (1971) presented data on uniaxial compressive strength and direct shear strength indicating that frozen till (grain-size and ice content not specified), at temperatures close to freezing, has a similar shear strength but a lower compressive strength (both instantaneous and creep) than frozen sand. The failure envelopes of Sayles, then, may be considered as rough approximations to (or maximum limits for) till-failure envelopes, especially for sandy till such as that at Waukesha.

To determine if the stress conditions under the ice at the site of the Waukesha drumlins are sufficient to cause ductile failure of frozen till and sand, the stresses on a unit volume of material must be specified. Assuming a polar glacier, a plausible ice profile is that of Antarctic ice: $h=$ $4.7\left(x^{0.5}\right)$, where $h$ is the ice thickness and $x$ is the distance from the margin (Hollin, 1962). The Waukesha drumlins are approximately $50 \mathrm{~km}$ from the margin at the Darien moraine (Fig. 1); thus, $h=1051 \mathrm{~m}$. (Note that the Kettle moraine, although much closer to the drumlins, is an interlobate moraine and so does not mark the origin of an uninterrupted ice profile.) The unit weight $(y)$ of ice at $-4^{\circ} \mathrm{C}$ is equal to the density of ice $\left(999 \mathrm{~kg} \mathrm{~m}^{-3}\right)$ multiplied by the acceleration due to gravity $\left(9.81 \mathrm{~m} \mathrm{~s}^{-2}\right)$; thus, $y=$ $9800 \mathrm{~N} \mathrm{~m}^{-3}$. The normal stress on the bed $\left(\sigma_{n}\right)$ is equal to the unit weight of the ice multiplied by the height of the overlying ice column $(=y h)$. At Waukesha, then, $\sigma_{n}=$ $10300 \mathrm{kN} \mathrm{m}^{-2}$. The ice surface slope $(\alpha)$ is obtained by taking the arc tangent of the derivative of the profile equation

$$
\alpha=\arctan \frac{d h}{d x}=\arctan \left[\frac{4.7}{2\left(x^{0.5}\right)}\right] .
$$

At $x=50000 \mathrm{~m}, \alpha=0.60^{\circ}$. The basal shear stress $(\tau)$ is given by the equation $\tau=y h \sin \alpha$. In this case, then, $T$ $=108 \mathrm{kN} \mathrm{m}^{-2}$. The horizontal confining pressure $\left(\sigma_{\mathrm{h}}\right)$ on a unit volume of sediment can be approximated by using the coefficient of Earth pressure $(K)$, which is the ratio of horizontal $\left(\sigma_{h}\right)$ to vertical $\left(\sigma_{\mathrm{v}}\right)$ stress on material below the Earth's surface. For frozen sediment where pore pressure is negligible, the normal stress is equal to the effective stress, and $\sigma_{\mathrm{h}}=K \sigma_{\mathrm{v}}$ (Sowers, 1979). $K$ is related to Poisson's ratio - the ratio of transverse to longitudinal strain - by the equation (Sowers, 1979) $K=v /(1-v)$, where $v$ is the Poisson's ratio for the material in question. Tsytovich ([c1975]) reported Poisson's ratios of 0.41 for frozen sand at $-0.2^{\circ} \mathrm{C}$, falling to 0.13 at $-0.8^{\circ} \mathrm{C}$. For a frozen silty loam at $-0.3^{\circ} \mathrm{C}$ he reported a Poisson's ratio of 0.35 , decreasing rapidly to 0.18 at $-0.8^{\circ} \mathrm{C}$, and levelling off at 0.13 as temperatures fall below $-1.5^{\circ} \mathrm{C}$. The Poisson's ratio for the 
sandy loam till at Waukesha, to extrapolate from these values, would be in the range of $0.10-0.13$ for temperatures of about $-4^{\circ} \mathrm{C}$, yielding a $K$ value of approximately 0.14 . Thus, given these assumptions, and observing that beneath the glacier the vertical stress $\left(\sigma_{\mathrm{v}}\right)$ is equal to the basal normal stress $\left(\sigma_{\mathrm{n}}\right)$, one finds that $\sigma_{\mathrm{h}}=K \sigma_{\mathrm{n}}=14\left(\begin{array}{ll}10 & 300\end{array}\right)=$ $1400 \mathrm{kN} \mathrm{m}^{-2}$. The resulting Mohr circle, both with and without basal shear stress added, is shown in Figure 9.

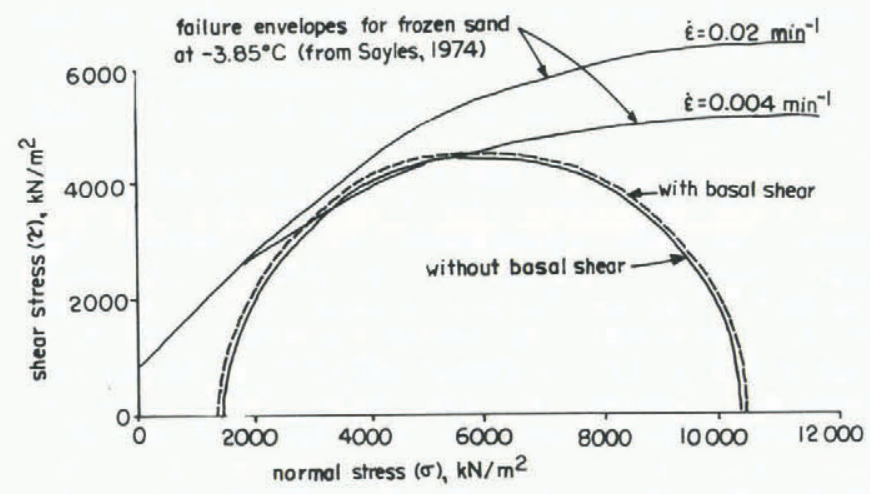

Fig. 9. Mohr circle for subglacial stress conditions at Waukesha during maximum extent of the ice, assuming an Antarctic-type ice-surface profile, a temperature of approximately $-5^{\circ} \mathrm{C}$ and a Poisson's ratio of 0.10 for the frozen subglacial sediment.

It is clear from the figure that the postulated stress conditions intersect the creep-failure envelope of frozen sand experiencing a strain-rate of $0.24 \mathrm{~s}^{-1}\left(0.004 \mathrm{~min}^{-1}\right)$. Moreover, the strain-rate of ice (and, by extension, a ball-park estimate of the strain-rate of deforming subglacial sediment) under a shear stress of $100 \mathrm{kN} \mathrm{m}^{-2}(=1 \mathrm{bar})$,
according to Glen's law, is on the order of $6 \times 10^{-9} \mathrm{~s}^{-1}$ (Paterson, 1969). Such slow strain-rates, to extrapolate from Sayles' findings, would further lower the yield strength and increase the likelihood of viscous flow. On the other hand, yield strengths increase linearly as temperature decreases. The exact form of the relationship depends on strain-rate and grain-size (Sayles and Haines, 1974; Tsytovich [ ${ }^{c} 1975$ ]; Haynes and Karalius, 1977); however, a drop in temperature from $-1{ }^{\circ} \mathrm{C}$ to $-15^{\circ} \mathrm{C}$ can nearly double the yield strength of frozen sand (Tsytovich, $\left[{ }^{c} 1975\right]$ ). Thus, the likelihood of flow of frozen sediment decreases rapidly as temperatures fall.

In conclusion, flow will occur in either wet or frozen till and sand if the yield strength of the sediment is exceeded. Although laboratory data on the strength of wet and saturated sediment are lacking, the morphologic evidence of squeeze-up till ridges near the margins of present-day glaciers, and the common occurrence of soft-sediment deformation in non-glacial environments, suggests that yield strengths of wet sediment are sufficiently low under certain pore pressures to readily permit flow if a differential stress is applied. The case for flow of frozen sediment is more complex because the yield strength depends on the strain-rate, temperature, grain-size, and ice content of the till. Assuming a temperature of approximately $-4^{\circ} \mathrm{C}$ and an Antarctic-type ice-surface profile, and assuming that the rheologic behavior of the till and sand at Waukesha is roughly similar to that of frozen sand with an ice-to-soil ratio of 0.6 , it appears that the yield strength would be exceeded and that the till and sand would be able to flow from regions of high normal stress on the bed into loci of low normal stress on the bed. Loci of low normal stress would occur where the weight of overlying ice is lowered, for example, beneath thinned ice or clear ice. We suggest that these mark the position of future drumlin sites. Thus, these considerations do not argue for or against the suggestions of Baranowski (1979) that drumlins represent frozen parts of the glacier bed.

\section{GENESIS OF THE DRUMLINS}

Drumlins are streamlined subglacial landforms that present minimum drag to ice flow around an obstacle (Chorley, 1959). As such, two questions seem pertinent to the origin of drumlins: (1) how was the obstacle produced, and (2) how was streamlining achieved? As emphasized by Boulton (1976), drumlins are morphologically defined landforms and, since a number of processes may produce similar or identical morphologies, there need not be a single origin for all drumlins. Thus, there are no doubt several correct answers to the above questions and any postulated origin for drumlins applies, of necessity, to a specific set of drumlins.

With this limitation in mind, we suggest the following sequence of events in the formation of the drumlins in south-eastern Wisconsin (modified from Whittecar and Mickelson (1979)):

(1) Basal till is deposited in a marginal zone as the ice advances, resulting in a sheet of till blanketing the pre-advance drift topography.

(2) Till and underlying sand and gravel, if mobile, flow laterally into sites on the bed where the effective stress is low. Perhaps this is beneath the thinnest ice (for example, perhaps below an intensely crevassed area or an "erosional mark" as proposed by Shaw (1983), or cleanest ice). At these sites, the normal stress on the bed is lower than on surrounding parts of the bed and lateral flow of sediment continues until the weight distribution above an arbitrary horizon is equalized, that is, when the "thinned" ice column is compensated by a thickened sediment column (Fig. 10, panels 1 to 3 ). The observed thickening of the till from the margin to the core of the drumlins indicates accumulation of sediment at the drumlin site, and the observed presence of till fabric that is perpendicular to ice flow, and of recumbent folds in sand with axes parallel to ice flow in the margins of the drumlin, is evidence for lateral sediment flow towards the drumlin site. The sediment accumulations that result from this flow are drumlin nuclei; they are obstacles to ice flow, and consist of sediment that

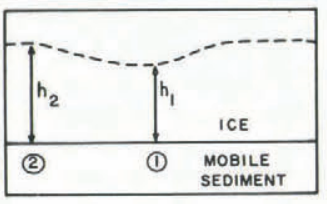

I. PRIOR TO LATERAL FLOW OF SEDIMENT.

$$
\begin{aligned}
\sigma_{1} & =\gamma_{\text {ICE }} h_{1} \\
\sigma_{2} & =\gamma_{\text {ICE }} h_{2} \\
h_{1} & <h_{2} \\
\therefore \sigma_{1} & <\sigma_{2}
\end{aligned}
$$

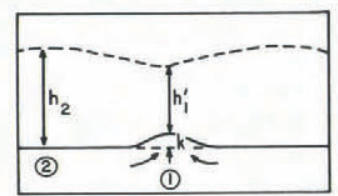

2. INITIATION OF LATERAL SEDIMENT FLow.

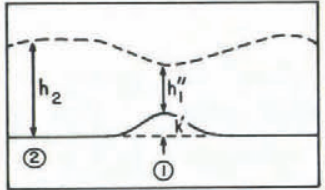

$$
\begin{gathered}
\sigma_{1}=\gamma_{\text {ICE }} h_{1}^{\prime}+\gamma_{\text {SEDIMENT }}{ }^{k} \\
\sigma_{2}=\gamma_{\text {ICE }} h_{2} \\
\gamma_{\text {SEDIMENT }}>\gamma_{\text {ICE, }} h_{1}^{\prime}<h_{1} \\
\therefore \sigma_{1} \text { APPROACHES } \sigma_{2} \text { IN MAGNITUDE } \\
\text { AS FLOW CONTINUES. }
\end{gathered}
$$

3. TERMINATION OF LATERAL SEDIMENT FLOW.

$$
\begin{aligned}
& \sigma_{1}=\gamma_{\text {ICE }} h_{1}^{\prime \prime}+\gamma_{\text {SEDIMENT }} k^{\prime} \\
& \sigma_{2}=\gamma_{\text {ICE }} h_{2} \\
& k^{\prime}>k \text { SUCH THAT } \sigma_{1}=\sigma_{2}
\end{aligned}
$$

$$
\therefore \text { FLOW STOPS BECAUSE THERE IS }
$$

NO STRESS GRADIENT.

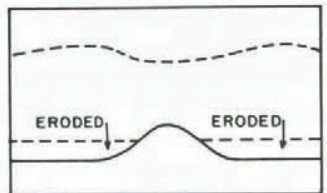

4. DEFINITION OF DRUMLIN BY EROSION AND REMOLDING OF THE SEDIMENT ACCUMULATION INTO A STREAMLINED SHAPE.

Fig. 10. Diagrammatic cross-sections perpendicular to ice flow, depicting the proposed sequence of events during drumlin formation. Great vertical exaggeration. Change in ice thickness could be due to crevassing. Similar results could be produced by differences in density of the overlying column but with equal ice thickness. 
can be shaped by erosion and remolding into a streamlined form.

If the sediment is completely frozen, flow will occur only under special combinations of ice thickness, temperature, strain-rate, and ice content. However, if the sediment is unfrozen or partially frozen, increases in pore pressure that are not matched by equivalent increases in normal stress will reduce the effective stress, lower the shear strength, and readily enhance sediment mobility. Such increases in pore pressure could be produced by rapid loading and compaction of slowly drained or undrained sediment due to ice advance (Vaiden and others, 1982) and by blockage of pre-glacial ground-water discharge areas by ice. Drainage of the subglacial water, in turn, would be impaired or halted by aquitards (Clayton and Moran, 1974) and by freezing of the glacier on to a permafrost bed at the margin (Mickelson and Clayton, 1981). Thus, advance of ice over water-bearing sediment induces abnormally elevated (excess) pore pressure in the sediment and thereby creates conditions favorable for drumlin nucleation.

Atop subglacial uplands the ice is thinner, and the normal stress less, than over subglacial lowlands. If the pore pressure is approximately constant throughout the subglacial sediment, the thinner ice on the uplands results in lower effective stress and more mobile sediment than in lowlands. The magnitude of this reduction, assuming a pre-glacial relief of approximately $100 \mathrm{~m}$ and an ice thickness of approximately $1000 \mathrm{~m}$ (see above), is on the order of $10 \%$ - a fraction that could be significant if the sediment is nearly mobile. Sediment flow and drumlin nucleation therefore occurs preferentially on upland areas beneath the ice, accounting for the observed clustering of drumlins on uplands.

Thus, we feel that much sediment movement takes place because of local differences in effective stress rather than shear stress due to ice flow as proposed by many (e.g. Boulton, 1982). This mechanism could be used in conjunction with the proposal by Shaw (1983) that drumlins form in erosional marks at the base of the ice, although the mechanism for producing the erosion marks is undocumented. Our observations of the character of the sand and gravel, in places the flat upper surface of the gravel, the accordant levels of the gravel in drumlins, and radiocarbon-dated wood from the gravel, indicate that the gravel pre-existed the drumlin formation. The gravel is not a cavity filling deposited beneath the ice.

(3) The accumulation of material in these proto-drumlin sites presents an obstruction to ice flow and flow lines are diverted around the obstacle. Strengthening of the obstruction may occur by dissipation of pore water through underlying sand and gravel, as suggested by Menzies (1979[a]). Streamlining of the obstruction into the minimum-drag drumlin shape is achieved by remolding and erosion (Fig. 10, panel 4). Till in the center of the drumlin flows into a streamlined shape in response to shear transmitted from over-riding ice seeking a flow pattern of minimum drag. Higher ice-flow velocities (and possibly freezing-on conditions) on the drumlin flanks and inter-drumlin areas promote extensive erosion of the till and underlying outwash from these areas, also emphasizing the streamlined form. In the field, truncation of the till and bedded sand and gravel at the drumlin flanks attests to the extensive erosion of inter-drumlin areas, and the prevalence of till fabric parallel to ice flow, especially close to the drumlin surface above perpendicular fabric, may reflect local remolding from over-riding ice.

(4) Next, another basal till is deposited as a carpet over the drumlinized topography, either during retreat of the ice or under thick ice shortly after formation of the drumlins.

(5) Lastly, a discontinuous drape of supraglacial till is deposited on the landscape during final melting of the ice.

On a regional scale, the occurrence of drumlins in a belt behind the ice margin may mark the location of a zone of ice that is partially frozen to the bed. This zone, in turn, marks the transition from a frozen bed at the margin to an unfrozen bed farther up-glacier. On the basis of geomorphologic evidence, Mickelson and Clayton (1981) argued that a frozen bed was present at the margin of the Green Bay lobe and the northern Lake Michigan lobe during late Wisconsin time. As mentioned above, this might allow high pore pressure to develop in unfrozen-bed areas behind the margin. Erosion would occur in areas where ice under compressive flow was freezing on to the bed and thereby lifting material off the bed. These observations suggest that the drumlins may have formed in the unfrozen-bed parts of the partially frozen zone where mobile sediment was present and that inter-drumlin areas, where extensive erosion has occurred, may represent frozen-bed parts or zones of freezing-on.

\section{ACKNOWLEDGEMENTS}

The authors would like to thank Drs P. Bosscher, L. Clayton, and C. Craddock for their helpful comments during manuscript preparation and on the manuscript itself. Field work was supported by the Wisconsin Alumni Research Foundation.

\section{REFERENCES}

Alden, W.C. 1905. The drumlins of southeastern Wisconsin U.S. Geological Survey. Bulletin 273, p. 9-46.

Alden, W.C. 1918. The Quaternary geology of southeastern Wisconsin. U.S. Geological Survey. Professional Paper 106.

Alkire, B.D., and Andersland, O.B. 1973. The effect of confining pressure on the mechanical properties of sand-ice materials. Journal of Glaciology, Vol. 12, No. 66 , p. $469-81$.

Baranowski, S. 1979. The origin of drumlins as an ice-rock interface problem. Journal of Glaciology, Vol. 23, No. 89, p. 435-36.

Boulton, G.S. [ $\left.{ }^{c} 1971.\right]$ Till genesis and fabric in Svalbard, Spitsbergen. (In Goldthwait, R.P., ed. Till: a symposium. [Columbus], $\mathrm{OH}$, Ohio State University Press, p. 41-72.)

Boulton, G.S. [ $\left.{ }^{c} 1975.\right]$ Processes and patterns of subglacial sedimentation: a theoretical approach. (In Wright, A.E., and Moseley, F., ed. Ice ages: ancient and modern. Liverpool, Seel House Press, p. 7-42. (Geological Journal, Special Issue No. 6.))

Boulton, G.S. 1976. The origin of glacially fluted surfaces observations and theory. Journal of Glaciology, Vol. 17 No. 76 , p. 287-309.

Boulton, G.S. 1982. Subglacial processes and the development of glacial bedforms. (In Davidson-Arnott, R., and others, ed. Research in glacial, glacio-fluvial, and glaciolacustrine systems. Proceedings of the 6th Guelph Symposium on Geomorphology, 1980. Edited by $R$. Davidson-Arnott, $W$. Nickling, and B.O. Fahey. Norwich, Geo Books in association with Geomorphology Symposium, University of Guelph, p. 1-31.)

Chorley, R.J. 1959. The shape of drumlins. Journal of Glaciology, Vol. 3, No. 25, p. 339-44.

Clayton, L., and Moran, S.R. 1974. A glacial process-form model. (In Coates, D.R., ed. Glacial geomorphology. Binghamton, NY, State University of New York, p. 89-119.)

Donner, J.J., and West, R.G. 1957. The Quaternary geology of Brageneset, Nordaustlandet, Spitsbergen. Norsk Polarinstitutt. Skrifter, Nr. 109.

Evenson, E.B. 1971. The relationship of macro- and microfabric of till and the genesis of glacial landforms in Jefferson County, Wisconsin. (In Goldthwait, R.P., ed. Till: a symposium. [Columbus], $\mathrm{OH}$, Ohio State University Press, p. 345-64.)

Glen, J.W., and others. 1957. On the mechanism by which stones in till become oriented, by J.W. Glen, J.J. Donner, and R.G. West. American Journal of Science, Vol. 255, No. 3, p. 194-205.

Gravenor, C.P., and Meneley, W.A. 1958. Glacial flutings in central and northern Alberta. American Journal of Science, Vol. 256, No. 10, p. 715-28.

Grieco, M.R. Unpublished. Drumlin origins as interpreted from till fabrics. [M.Sc. thesis, Syracuse University, 1977.] 
Harrison, P.W. 1957. A clay-till fabric: its character and origin. Journal of Geology, Vol. 65, No. 3, p. 275-308.

Haynes, F.D., and Karalius, J.A. 1977. Effect of temperature on the strength of frozen silt. CRREL Report (Hanover, NH) 77-3.

Hill, A.R. 1971. The internal composition and structure of drumlins in north Down and south Antrim, Northern Ireland. Geografiska Annaler, Vol. 53A, No. 1, p. 14-31.

Hollin, J.T. 1962. On the glacial history of Antarctica. Journal of Glaciology, Vol. 4, No. 32, p. 173-95.

Holmes, C.D. 1941. Till fabric. Bulletin of the Geological Society of America, Vol. 52, p. 1299-354.

Johnson, A.M. 1970. Physical processes in geology. San Francisco, Freedom Cooper.

Johnson, M.D., and others. 1982. Lodgement till, meltout till, supraglacial debris: can they be distinguished in sequences of Pleistocene age?, by M.D. Johnson, D.M. Mickelson, J.W. Attig, S.D. Stanford, S. Boley-May, and B. Socha. Geological Society of America. North Central Section. Abstracts with Programs, Vol. 14, No. 5, p. 263.

Kamb, W.B. 1959. Ice petrofabric observations from Blue Glacier, Washington, in relation to theory and experiment. Journal of Geophysical Research, Vol. 64, No. 11, p. 1891-909.

Kaplar, C.W. 1971. Some strength properties of frozen soil and effect of loading rate. CRREL Special Report 159.

Krüger, J., and Thomsen, H.H. 1984. Morphology, stratigraphy, and genesis of small drumlins in front of the glacier Myrdalsjökull, south Iceland. Journal of Glaciology, Vol. 30, No. 104, p. 94-105.

McKee, E.D., and others. 1962. Experiments on intraformational recumbent folds in cross-bedded sand, by E.D. McKee, M.A. Reynolds, and C.H. Beker. U.S. Geological Survey. Professional Paper 450-D, p. 155-59.

MacClintock, P., and Dreimanis, A. 1964. Reorientation of till fabric by overriding glacier in the St. Lawrence Valley. American Journal of Science, Vol. 262, No. 1, p. 133-42.

Menzies, J. 1979[a]. The mechanics of drumlin formation with particular reference to the change in pore-water content of the till. Journal of Glaciology, Vol. 22, No. 87, p. 373-84

Menzies, J. 1979[b]. A review of the literature on the formation and location of drumlins. Earth-Science Reviews, Vol. 14, p. 315-59.

Mickelson, D.M., and Clayton, L. 1981. Subglacial conditions and processes during Middle Woodfordian time in Wisconsin. Geological Society of America. North Central Section. Abstracts with Programs, p. 30.

Mickelson, D.M., and others. 1984. Pleistocene stratigraphic units of Wisconsin, by D.M. Mickelson, L. Clayton, R.W. Becker, W.N. Mode, and A.F. Schneider. Wisconsin Geological and Natural History Survey. Miscellaneous Paper 84-1.

Mills, H.H., jr. 1980. An analysis of drumlin form in the northeastern and north-central United States: summary. Geological Society of America. Bulletin, Vol. 91, No. 11, p. 637-39.

Mills, H.H., jr. Unpublished. The variation of drumlin form. [M.Sc. thesis, University of North Carolina at Chapel Hill, 1972.]

Paterson, W.S.B. 1969. The physics of glaciers. Oxford, etc., Pergamon Press.

Peterson, G.L. 1968. Flow structures in sandstone dikes. Sedimentary Geology, Vol. 2, p. 177-90.

Potter, P.E., and Pettijohn, F.J. 1963. Paleocurrents and basin analysis. New York, Academic Press.

Rusnak, G.A. 1957. The orientation of sand grains under conditions of "unidirectional" fluid flow. Journal of Geology, Vol. 65, p. 384-409.
Savage, W.Z. Unpublished. Application of plastic flow analysis to drumlin formation. [M.Sc. thesis, Syracuse University, 1968.]

Sayles, F.H. 1974. Triaxial constant strain rate tests and triaxial creep tests on frozen Ottawa sand. CRREL Technical Report 253.

Sayles, F.H., and Haines, D. 1974. Creep of frozen silt and clay. CRREL Technical Report 252.

Scott, R.F. 1969. The freezing process and mechanics of frozen ground. CRREL Monograph (Hanover, NH) II-D1.

Shaw, J. 1983. Drumlin formation related to inverted melt-water erosional marks. Journal of Glaciology, Vol. 29, No. 103, p. 461-79.

Shaw, J., and Freschauf, R.C. 1973. A kinematic discussion of the formation of glacial flutings. Canadian Geographer, Vol. 17, No. 1, p. 19-35.

Smalley, I.J. 1966. Drumlin formation: a rheological model. Science, Vol. 151, No. 3716, p. 1379-80.

Smalley, I.J. 1981. Conjectures, hypotheses, and theories of drumlin formation. Journal of Glaciology, Vol. 27, No. 97 , p. 503-05.

:r.r.

Smalley, I.J., and Unwin, D.J. 1968. The formation and shape of drumlins and their distribution and orientation in the drumlin fields. Journal of Glaciology, Vol. 7, No. 51, p. $377-90$.

Sowers, G.F. 1979. Introductory soil mechanics and foundations: geotechnical engineering. New York, Macmillan.

Sugden, D.E., and John, B.S. 1976. Glaciers and landscape: a geomorphological approach. London, Edward Arnold.

Tsytovich, N.A. [ $\left.{ }^{\mathrm{C}} 1975.\right]$ The mechanics of frozen ground. Edited by G.K. Swinzow. Washington, DC, Scripta Book Co.; New York, etc., McGraw-Hill Book Co. (McGraw-Hill Series in Modern Structures.)

Vaiden, R., and others. 1982. A possible paleo-overpressured sand in glacial deposits of central Illinois, by R. Vaiden, K. Cartwright, and J.P. Kempton. Geological Society of America. North Central Section. Abstracts with Programs, p. 290.

Walker, M.J.C. 1973. The nature and origin of a series of elongated ridges in the Morley Flats area of the Bow Valley, Alberta. Canadian Journal of Earth Sciences, Vol. 10, No. 8 , p. $1340-46$.

Waterson, C.B. 1950. Note on the sandstone injections of Eathie Haven, Cromarty. Geological Magazine, Vol. 87, p. 133-39.

West, R.G. 1977. Pleistocene geology and biology. London, Longman.

Whittecar, G.R. Unpublished. The glacial geology of the Waukesha drumlin field, Waukesha County, Wisconsin. [M.Sc. thesis, University of Wisconsin-Madison, 1976.]

Whittecar, G.R., and Mickelson, D.M. 1977. Sequence of till deposition and erosion in drumlins. Boreas, Vol. 6, No. 2, p. 213-17.

Whittecar, G.R., and Mickelson, D.M. 1979. Composition, internal structures, and an hypothesis of formation for drumlins, Waukesha County, Wisconsin, U.S.A. Journal of Glaciology, Vol. 22, No. 87, p. 357-71.

Williams, E. 1960. Intra-stratal flow and convolute folding. Geological Magazine, Vol. 97, p. 208-14.

Wright, H.E., jr. 1957. Stone orientation in Wadena drumlin field, Minnesota. Geografiska Annaler, Vol. 39, Ht. 1, p. 19-31.

Young, J.A.T. 1969. Variations in till macrofabric over very short distances. Geological Society of America. Bulletin, Vol. 80 , No. 11, p. 2343-52. 